\title{
Estimation of Effective Stress by Geo-electric Characterization at a Proposed Solar Power Installation Site in Ajowa Akoko, Nigeria
}

\author{
AISABOKHAE, JE \\ Department of Applied Geophysics, Federal University Birnin Kebbi, Kebbi State, Nigeria \\ Email: joseph.aisabokhae@fubk.edu.ng
}

\begin{abstract}
Geo-electrical resistivity survey has been used for geotechnical investigation at a site proposed for solar power installations in Ajowa Akoko, Nigeria, to assist its foundation prognosis. Vertical electrical soundings (VES) were conducted in 24 locations spaced 50 meters apart with maximum AB/2 spread of 160 meters covering an area of $2 \mathrm{~km}^{2}$. Electrical characterization of subsurface layers was done to identify a maximum of four geo-electric subsurface layers comprising the top soil (clayey sand and laterite), weathered layer (zone of capillary rise), and highly weathered (saturated) layer and fresh basement. The concept of electrical resistivity variation with subsurface formations - related to degree of saturation, specific gravity of solids, void ratio and unit weight of water - has been used to calculate the effective stress of each soil layer obtained from pore water pressure and total stress data. The effective stress estimated over the surveyed area for the various depths of $1.5 \mathrm{~m}, 4.0 \mathrm{~m}$ and $19 \mathrm{~m}$ corresponding to the base of each characterized subsurface were $26.13 \mathrm{kN} / \mathrm{m}^{2}-44.00 \mathrm{kN} / \mathrm{m}^{2}, 73.80 \mathrm{kN} / \mathrm{m}^{2}$ and $181.19 \mathrm{kN} / \mathrm{m}^{2}$ respectively. The effective stress plot shows that the soil stability increases with depth in the surveyed location. The study demonstrates the usefulness of VES method in estimating geotechnical attributes for efficient and precise information.
\end{abstract}

\section{DOI: https://dx.doi.org/10.4314/jasem.v22i5.5}

Copyright: Copyright $@ 2018$ Aisabokhae. This is an open access article distributed under the Creative Commons Attribution License (CCL), which permits unrestricted use, distribution, and reproduction in any medium, provided the original work is properly cited.

Dates: Received: 12 March 2018; Revised: 17 April: 2018; Accepted: 21 April 2018

Keywords: effective stress, electrical characterization, geotechnical attributes.

Geophysical exploration techniques can serve as tools in various fields of studies including foundation assessment, stress estimation and lithological classification in geotechnical studies. The earth subsurface stratification play a major role in the stability and sustainability of top soils and its overlying structures. The composition of total stress, pore water pressure and effective stress in an area are good indices for geotechnical assessment of the stability and compatibility of the overburden for construction purposes. The total stress estimation is suitable for low permeability soils such as clay for long-term geotechnical analysis, and suitable for freedraining materials like sand and gravel on a short-term basis. This is because it is assumed that a long time will elapse before there is significant dissipation of pore pressure water in the case of cohesive soils.

As such, at the end of the construction, the soil is almost still undrained. The effective stress is more suitable for long-term soil analysis because after a relatively long period of time, the fully drained stage of the soil would have been reached as deformation of soil in the long term is a function of effective stresses and not total stress.

The compressibility and shearing resistivity of a soil depend to a great extent on the effective stress. Thus, the concept of effective stress is significant in solving geotechnical problems, such as lateral earth pressure on retaining structures, load-bearing capacity and settlement of foundation. The effective stress principle is probably the most important concept in geotechnical engineering. In this study, several electrical resistivity soundings were carried out in the survey site. According to Okoli (2004), earth subsurface resistivities are related to important geologic parameters viz type of rocks and soils, porosity and degree of saturation.

These findings can necessitate possible hydrogeological interpretations of the measured electrical resistivity at the survey area such as; determination of depth to and thickness of potential aquifer horizon, establishment of groundwater formation and mapping of desirable points for optimal groundwater recharge. Similarly, a geotechnical interpretation of the resistivity data can aid the foundation characterization of near-surface layers by describing the nature of the subsurface lithology, the extent of underlain earth materials and the effective stress.

The objectives of this study was to assess geotechnical conditions and estimate total stress, pore water pressure and effective stress parameters. 


\section{MATERIALS AND METHODS}

The Basic Equations and Analytical Techniques: The total stress at the elevation of a point can be obtained from the saturated unit weight of the soil and the unit weight of water above it. Thus,

$\sigma=\mathrm{Hy}_{\mathrm{w}}+\left(\mathrm{H}_{\mathrm{A}}-\mathrm{H}\right) \mathrm{y}_{\mathrm{sat}}$

Where, $\sigma=$ total stress at the elevation point, $\mathrm{y}_{\mathrm{w}}=$ unit weight of water, $\mathrm{y}_{\mathrm{sat}}=$ saturated unit weight of soil, $\mathrm{H}$ $=$ height of water table from the top of the soil column, $\mathrm{H}_{\mathrm{A}}=$ distance between point $\mathrm{A}$ and the water table

The principle of effective stress in relation with normal stress given as

$\sigma=\sigma^{\prime}+\mathrm{u} \ldots$

Where, $\sigma=$ total stress, $\sigma^{\prime}=$ effective stress, and $\mathrm{u}=$ pore water pressure

This was first developed by Terzaghi et al., (1948). Effective stress is approximately the force per unit area carried by the soil skeleton. The effective stress in a soil mass controls its volume change and strength. Increasing the effective stress induces soil to move into denser state of packing (Das, 1987). Hence,

$\mathrm{y}_{\mathrm{sat}}=\frac{\left(G_{S}+S e\right) \mathrm{y}_{w}}{1+e}$

Where, $\mathrm{S}=$ degree of saturation, $\mathrm{e}=$ void ratio and $\mathrm{G}_{\mathrm{s}}$ $=$ specific gravity of solids.

A tabular representation of specific gravity of various solids is given in Table 1. The degree of saturation can be estimated directly from the fraction of a unit crosssectional area of the soil occupied by water given by $\mathrm{X}$. For dry soil $\mathrm{X}=0$ and for saturated soil $\mathrm{X}=1$. Bishop (1960) had pointed out that the intermediate values of $X$ will depend primarily on the degree of saturation (and vice versa) as illustrated in figure 1.

Table 1: Specific gravity of some soils (Das, 1987)

\begin{tabular}{ll}
\hline Soil formation & Specific gravity of solid $\left(\mathbf{G}_{\mathbf{s}}\right)$ \\
\hline Dry sand & 2.65 \\
Saturated clay & 2.71 \\
Wet sand & 2.67 \\
Dry clay & 2.68 \\
\hline
\end{tabular}

The void ratio can also be calculated by

$\mathrm{e}=\frac{G_{S} w}{S}$

The void ratio (e) is estimated at 0.52 in dry soils while keeping the unit weight of water at 9.8 in saturated soils (Budhu et al., 2000). The moisture content $(\boldsymbol{w})$ is a percentage of the soil that is damp. Also, the pore water pressure (hydrostatic pressure) is given as:

$\mathrm{u}=\mathrm{HY}_{\mathrm{w}} \quad$ (immediately above the datum plane) .

Or, $\mathrm{u}=-\left(\mathrm{SY}_{\mathrm{w}} \mathrm{H}_{2}\right) \quad$ (immediately below the datum plane)..(6)

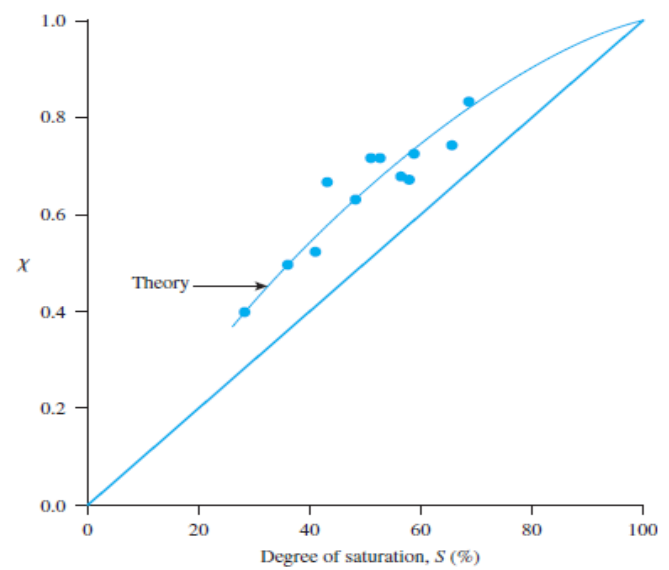

Fig 1: Relationship between the parameter $\mathrm{X}$ and degree of saturation (Bishop et al., 1960)

Below the water table, pore pressures are positive. In dry soils, pore pressure is zero. Above the water table, when the soil is saturated, pore pressure will be negative. When load is applied to soil, it is carried by the water in the pores as well as the solid grains. The increase in pressure within the pore water causes drainage and the load is transferred to the solid grains. The strength and compressibility of the soil depend on the stresses within the solid granular fabric. The critical shear strength of soil is proportional to the effective stress.

All measurable effects of a change of stress, such as compression, distortion and a change of shearing resistance are due exclusively to change in effective stress. It does not represent the exact contact stress between particles but the distribution of load carried by the soil over the area considered (Das, 1987).

Geological context: Ajowa Akoko is situated in Akoko North West local government area of Ondo State in the Southwestern part of Nigeria, as shown in figure 2 . The entire study area lies within the longitude $5^{\circ} 47^{\prime} \mathrm{E}$ and $5^{\circ} 56^{\prime} \mathrm{E}$, and latitude $7^{\circ} 38^{\prime} \mathrm{N}$ and $7^{\circ} 47^{\prime} \mathrm{N}$. Ajowa covers an estimated area of about $7 \mathrm{~km}^{2}$. The area mapped is a part of the crystalline basement complex of Southwestern Nigeria (Short et al., 1995) as seen in figure 3 . The major rock types found in the area are: migmatite gneiss (granite gneiss, grey gneiss), charnockitic rock, quartzite and granite that are part of older granite suite of Nigeria. These rocks have been subject to various deformations such as: metamorphic deformation, shearing, microfolding, 
foliation and lineation, jointing, faulting, etc., (Osemeikhian et al., 1994). There are some minor rock types exhibited within these major rocks, these include pegmatite, apite, dolerite dykes and biotite granite.

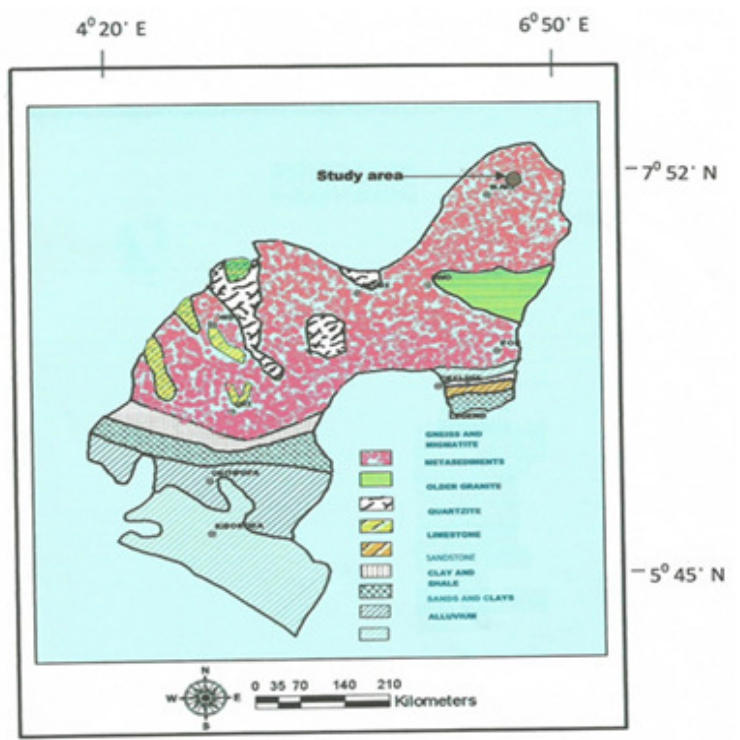

Fig 2: Geologic map of Akoko

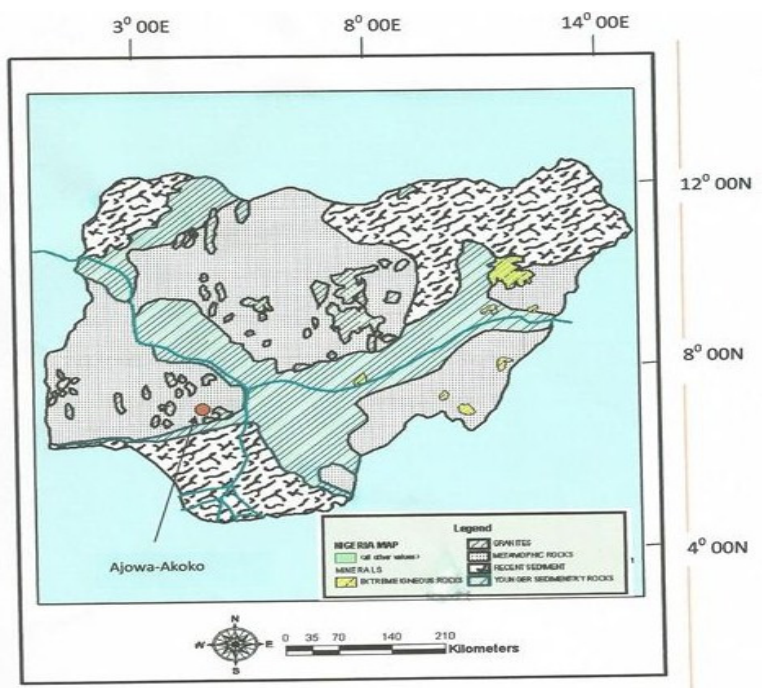

Fig 3: Geologic Map of Nigeria showing study area (Osemeikhian et al., 1994)

All these minor rocks are found as intrusions within the major rock types and are of varying sizes and directions. Some cut across the host rock in various directions to the direction of strikes of the major rock while others intrude into the major rock in the same direction as the rock.
Field Procedure: A SYSCAL resistivity meter adopting Schlumberger electrode array was used for the data collection on the field. A total of twenty four vertical electrical sounding (VES) stations measuring 20 meters apart were occupied across the entire site. The sounding curves were subjected to a preliminary interpretation using the partial curve matching technique. 1-D analysis of the sounding curves was made with an average RMS error of $2.5 \%$. In subsequent analysis, the results of the 1-D inversion i.e. layer parameters were compiled and processed to generate total stress, pore water pressure and effective stress data of the area.

\section{RESULTS AND SYNOPSIS}

The selected VES points where interpreted individually to generate data for geotechnical analysis. For VES 1, the type-curve derived from the model was a typical "QH" curve. The model delineated four geoelectric sequences which are: a highly resistive thick top soil with resistivity of $1058 \mathrm{ohm}-\mathrm{m}$ and thickness of $2.5 \mathrm{~m}$, a weathered second layer with resistivity of $258 \mathrm{ohm}-\mathrm{m}$ and thickness of $1.1 \mathrm{~m}$, a highly weathered (and probably highly saturated) third layer with resistivity of $41 \mathrm{ohm}-\mathrm{m}$ and thickness of $16.8 \mathrm{~m}$ and the fractured basement with a resistivity of $242 \mathrm{ohm}-$ $\mathrm{m}$. The vertical electrical sounding done did not probe to the fresh basement. The depth to the fractured basement was $20.5 \mathrm{~m}$.

For VES 2, the type-curve derived from the model was also a typical "QH" curve. The model delineated four geo-electric sequences which are: a highly resistive top soil with resistivity of $2033 \mathrm{ohm}-\mathrm{m}$ and thickness of $1.5 \mathrm{~m}$, a weathered second layer with resistivity of $304 \mathrm{ohm}-\mathrm{m}$ and thickness of $3.4 \mathrm{~m}$, a highly weathered (and probably highly saturated) third layer with resistivity of $34 \mathrm{ohm}-\mathrm{m}$ and thickness of $34.8 \mathrm{~m}$ and the fresh basement with a resistivity of $800 \mathrm{ohm}-\mathrm{m}$. The depth to the fresh basement was estimated as 39.7 m. For VES 4, the type-curve derived from the model was also a typical "QH" curve. The model delineated four geo-electric sequences which are: a highly resistive top soil with resistivity of $1185 \mathrm{ohm}-\mathrm{m}$ and thickness of $0.9 \mathrm{~m}$, a weathered second layer with resistivity of $123 \mathrm{ohm}-\mathrm{m}$ and thickness of $3.3 \mathrm{~m}$, a highly weathered (and probably highly saturated) third layer with resistivity of $30 \mathrm{ohm}-\mathrm{m}$ and thickness of $19.8 \mathrm{~m}$ and the fresh basement with a resistivity of 798 ohm-m. The depth to the fresh basement was estimated as $24.1 \mathrm{~m}$. 

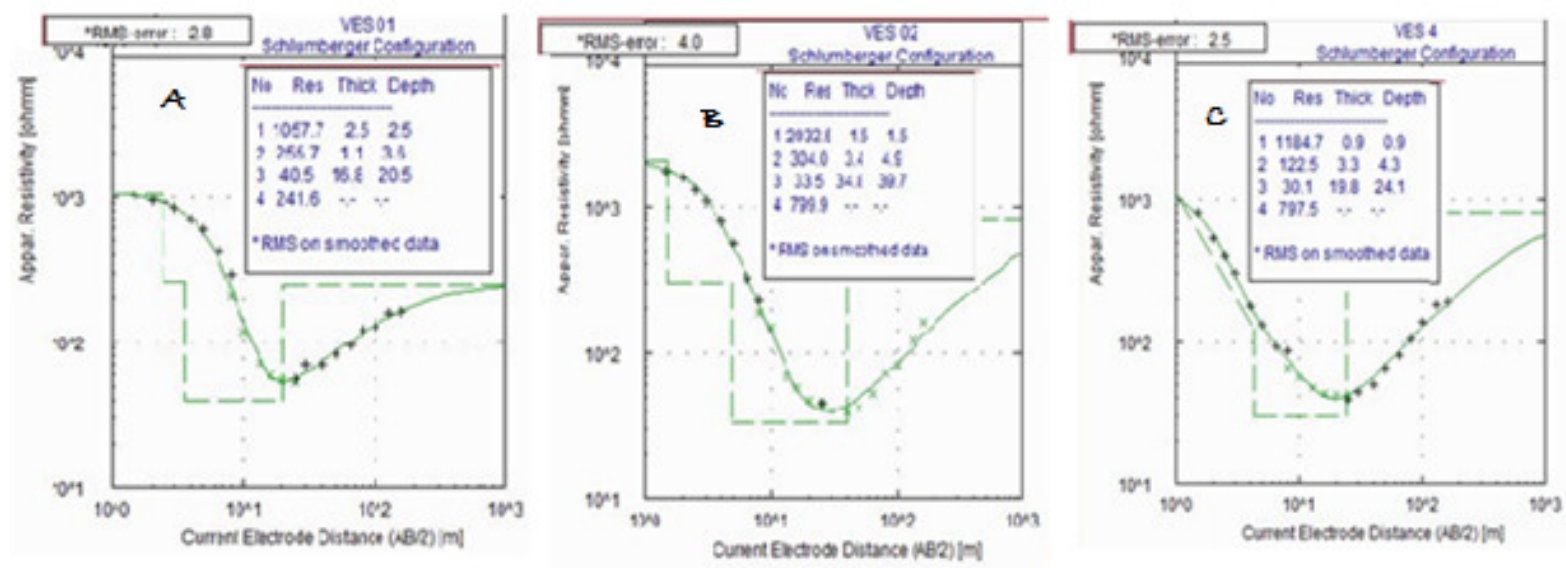

Figure 4: Typical sounding curves for the study area (a) VES 1 (b) VES 2 (c) VES 4

\begin{tabular}{lll}
\multicolumn{3}{c}{ Table 2: Layer characterization with depths } \\
\hline Soil Interface & Average Depth $(\mathbf{m})$ & Description \\
\hline Top Soil & 0.00 & Upper soil (dry sand) \\
At depth $\mathrm{H}_{1}$ & 1.50 & Zone of capillary rise \\
At depth $\mathrm{H}_{1}+\mathrm{H}_{2}$ & $1.50+2.50$ & Saturated weathered layer \\
At depth $\mathrm{H}_{1}+\mathrm{H}_{2}+\mathrm{H}_{3}$ & $1.50+2.50+15.00$ & Basement rock \\
\hline
\end{tabular}

Table 3: Results of values from analysis

\begin{tabular}{|c|c|c|c|c|c|c|}
\hline Soil Interface & $\begin{array}{l}\text { Depth } \\
\text { (m) }\end{array}$ & $\sigma$ & $\begin{array}{l}\mathbf{u} \\
\text { (immediatel } \\
\text { y above) }\end{array}$ & $\begin{array}{l}\text { U } \\
\text { (immediately } \\
\text { below) }\end{array}$ & $\begin{array}{l}\sigma^{\prime} \\
\text { (immediatel } \\
\text { y above) }\end{array}$ & $\begin{array}{l}\sigma \\
\text { (immediatel } \\
\text { y below) }\end{array}$ \\
\hline Top Surface & 0.00 & 0.00 & 0.00 & 0.00 & 0.00 & 0.00 \\
\hline At depth below top soil $\left(\mathrm{H}_{1}\right)$ & 1.50 & $26.13 \mathrm{kN} / \mathrm{m}^{2}$ & 0.00 & $-12.33 \mathrm{kN} / \mathrm{m}^{2}$ & $26.13 \mathrm{kN} / \mathrm{m}^{2}$ & $44.00 \mathrm{kN} / \mathrm{m}^{2}$ \\
\hline $\begin{array}{l}\text { At depth below weathered layer } \\
\left(\mathrm{H}_{1}+\mathrm{H}_{2}\right)\end{array}$ & 4.00 & $73.80 \mathrm{kN} / \mathrm{m}^{2}$ & 0.00 & & $73.80 \mathrm{kN} / \mathrm{m}^{2}$ & \\
\hline $\begin{array}{l}\text { At depth below inferred aquifer } \\
\left(\mathrm{H}_{1}+\mathrm{H}_{2}+\mathrm{H}_{3}\right)\end{array}$ & 19.00 & $329.12 \mathrm{kN} / \mathrm{m}^{2}$ & $147.93 \mathrm{kN} / \mathrm{m}^{2}$ & & $181.19 \mathrm{kN} / \mathrm{m}^{2}$ & \\
\hline
\end{tabular}

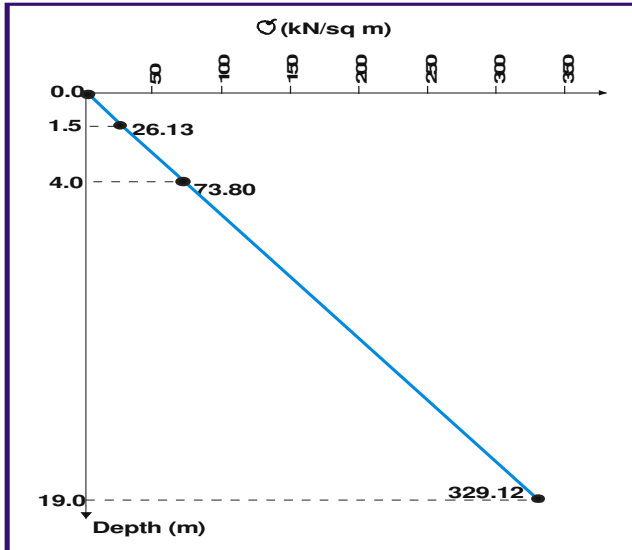

Fig 5a: A plot of total stress with depth

From the geo-electric sounding interpretations over the entire site of investigation, the VES curves have revealed a consistency in subsurface deposition starting from the top soil to the weathered layer which serves as the zone of capillary rise, then to a highly weathered aquiferous layer and finally, the basement rock as shown in Table 2. The Thicknesses of the top soils across the 24 randomly surveyed points in the area varied from $0.9 \mathrm{~m}$ to $2.8 \mathrm{~m}$; the thickness of the

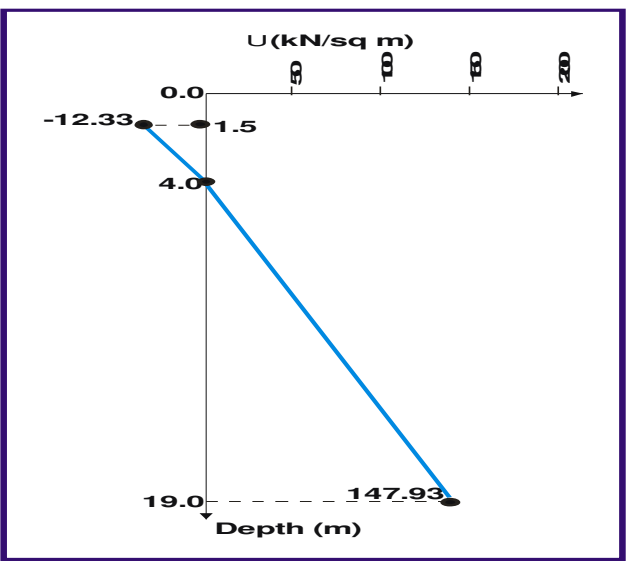

Fig 5b: A plot of pore water pressure with depth

zone of capillary rise varied from $3.3 \mathrm{~m}$ to $5.2 \mathrm{~m}$, while the thicknesses of the highly weathered saturated layer ranged from $9 \mathrm{~m}$ to $35 \mathrm{~m}$. The effective stress for geotechnical studies can be deduced by averaging the depths to the various geologic formations of all the VES results and imputing values for total stress and pore water pressure calculations (Schroeder et al., 2004). Table 3, presents the effective stress data of the surveyed area. 




Fig 5c: A plot of effective stress with depth.

Figure 5 shows the variation of total stress and effective stress with depth. This interpretation is used to distinguish between inter-granular stress and effective stress (Budhu, 2000). The effective stress estimated over the surveyed area for the various depths of $1.5 \mathrm{~m}, 4.0 \mathrm{~m}$ and $19 \mathrm{~m}$ corresponding to the base of the characterized sub-surfaces were $26.13 \mathrm{kN} / \mathrm{m}^{2}$ $44.00 \mathrm{kN} / \mathrm{m}^{2}, \quad 73.80 \mathrm{kN} / \mathrm{m}^{2}$ and $181.19 \mathrm{kN} / \mathrm{m}^{2}$ respectively. A comparison shows that the effective stress at a point located at any given depth measured from the surface of a soil layer is reduced by the weight of water because of upward seepage of water. If the rate of seepage and thereby the hydraulic gradient are increased, a limiting condition will be reached at which point the effective stress will be zero and under this condition, soil stability is lost (Das, 1987). The effective stress plot shows that the soil stability Increases with depth in the surveyed area.

Conclusion: This study has shown that geophysical prospecting using vertical electrical sounding is suitable to delineate subsurface stratigraphy. Interpretation of the VES data characterizes the geologic formations and their respective depths which can aid in geotechnical estimations such as total stress, pore water pressure and effective stress for site engineering purposes. This work has provided some critical information expected to assist in the planning and development of engineering designs for structures at the investigated site.

\section{REFERENCES}

Bishop, A; Alpan, I; Blight, G; Donald, IB (1960). Factors controlling the strength of partially saturated cohesive soils. Proceedings, Research Conference on shear strength of cohesive soils, ASCE. $502-532$

Budhu, D (2000). Soil Mechanics and Foundations. John Wesley and Sons Inc. New York.

Das, BM (1987). Principles of Geotechnical Engineering, Seventh Edition. Cengage Learning. Stanford, U.S.A.

Okoli, MH (2004). Electrical imaging surveys for Environmental and Engineering studies. Santo Services Limited. Lagos, Nigeria.

Oldlam, VP (1996). Applied and Environmental Geophysics. Cambridge University Press, Cambridge.

Osemeikhian, J; Asokia, M (1994). Applied Geophysics. Santo Services Limited. Lagos, Nigeria.

Pazdireck, G; Blaha, FC (1996). Electrical methods in geophysical prospecting. Pergamo Press Inc., Oxford.

Schroeder, W; Dickenson, S; Warrington; Don, C (2004). Soils in construction. Fifth Edition, Upper Saddle River, New Jersey, Prentice Hall.

Short, K; Stäublee, AJ (1995). Outline of geology of Niger Delta: American Association of Petroleum Geologists Bulletin. 51: 761-779

Terzaghi, K; Peck, RB (1948). Soil Mechanics in Engineering practice, Wiley, New York.

Zohdy, M (1964). An Introduction to Applied and Environmental Geophysics John Wiley and Sons Limited. West Sussex. England. 